\title{
Determining Variability in Characteristics of Residential Landscape Soils that Influences Infiltration Rates
}

\author{
Brian J. Pearson, Richard C. Beeson, Jr., Carrie Reinhart-Adams, Michael Olexa, and Amy Shober
}

\begin{abstract}
Although composed mostly of sand, observations of new urban residential communities in Florida suggested relatively wide ranges in clay content and importation of offsite soils. Often these communities are constructed around surface water where heavy summer rains and intense landscape maintenance present concerns for surface water contamination. Due to land sculpturing, soil compaction and importation; onsite soil physical properties may differ from soil maps developed decades before. How much change and what changes occurred has seldom been quantified. This study examined soil characteristic data from diverse, newly constructed urban soils and examined relationships with soil infiltration rates. Samples were collected from 40 lots in nine newly established urban residential communities within Central Florida to quantify textural composition, bulk density $\left(D_{\mathrm{b}}\right)$, moisture retention, and pore size distribution. Most lots $(90 \%)$ contained sandy soil dominated by micropores (58\% total mean pore space). Variability of $\mathrm{D}_{\mathrm{b}}$ was low with most communities exhibiting high soil compaction $\left(>1.7 \mathrm{~g} \mathrm{~cm}^{-3}\right)$, which may indicate potential plant root penetration concerns. Mean soil infiltration rates among communities were high $\left(11\right.$ to $\left.64 \mathrm{~cm} \mathrm{hr}^{-1}\right)$, with large variations $\left(2.0\right.$ to $\left.111.1 \mathrm{~cm} \mathrm{hr}^{-1}\right)$. Correlations between soil moisture retention volumes, $\mathrm{D}_{\mathrm{b}}$, and infiltration rate did not occur. However, soil texture was a significant predictor of infiltration rate. Relationships between infiltration rates and soil characteristics were poor $\left(\mathrm{r}^{2}=0.43\right)$ and suggest direct measurement of infiltration rate may be necessary. High infiltration rates, despite compaction, indicate reduced potential for surface water contamination if a sufficient natural fetch separates landscapes from water bodies.

Key Words. Bulk Density; Compaction; Florida; Residential; Sandy Soil; Soil Moisture; Storm Water; Urban Soil.
\end{abstract}

Urban residential population growth requires construction of roads, homes, and supporting infrastructure. Construction activities impact soil characteristics and often result in increased soil compaction, restricted aeration, and decreased water infiltration (Craul 1985). Although impacts of construction activities on soil characteristics are well understood, few studies have quantified soil characteristics in newly established urban residential landscapes (Craul 1991).

Compaction of urban residential landscape soil can be unintentional and a result of heavy equipment usage and site traffic, or deliberate to strengthen soils for engineered loads (Randrup and Dralle 1997). Soil compaction reduces soil porosity, resulting in reduced aeration, decreased drainage and water holding capacity (Craul 1985). Randrup and Dralle (1997) examined unintentional soil compaction within newly constructed commercial and residential sites and found that subsoil ( 0.4 to 0.8 $\mathrm{m}$ below soil surface) compaction was $8 \%$ greater in developed areas than undeveloped control locations. A similar study in Florida, U.S. examined the influence of residential construction on soil hydrology, and determined construction activities reduced infiltration rates by $80 \%$ and $99 \%$ in front and back portions of a developed lot, respectively (Gregory et al. 2006). Heavy equipment usage increased mean soil bulk density $\left(D_{b}\right)$ (from 1.34 to $1.49 \mathrm{~g} \mathrm{~cm}^{-3}$ ), causing corresponding decreases in mean infiltration rates (from 73.3 to $17.8 \mathrm{~cm} \mathrm{hr}^{-1}$ ). Florida soils are primarily dominated by sand particle size fractions (Brown et al. 1990). High bulk density $\left(>1.75 \mathrm{~g} \mathrm{~cm}^{-3}\right)$ can negatively impact plant root growth in sand-dominated soils (Daddow and Warrington 1983; Voorhees 1992). Reductions in soil macroporosity as a result of soil compaction leads to a restriction in soil water and air movement (Tuli and Hopmans 2004; Tuli et al. 2005). Low soil water infiltration rates may contribute to urban stormwater discharge during intense precipitation events, thus allowing for overland nutrient transport and water quality degradation (Brett et al. 2005; Atasoy et al. 2006).

Protective surface treatments can be used to reduce unintentional traffic-induced soil compaction during construction (Lichter and Lindsey 1994). However, this method has proven limited in effectively preventing soil compaction (Randrup and Dralle 1997). Techniques used to ameliorate soil compaction can be undertaken, although available methods are not universally effective (Day and Bassuk 1994). Randrup and Dralle (1997) proposed division of zones within construction areas to minimize soil compaction. Zoning would eliminate traffic in future planting areas and represents the best option to minimize compaction.

Studies that have examined soil bulk density (Pitt et al. 1999; Gregory et al. 2006), organic matter (Beyer et al. 1995; Scharenbroch et al. 2005), and microbial biomass (Lorenz and Kandeler 2006) in urban areas are available; however, few studies have specifically quantified urban soil characteristics within a broad range of newly constructed urban residential communities. Quantification of soil characteristics within these unique environments is needed to better understand the environmental impacts associated with urban construc- 
tion and development. Twelve percent of national stormwater nutrient runoff is estimated to originate from urban residential landscapes (USEPA 1994). Discharge of nutrients from urban stormwater sources within Florida are likely greater than national estimates due to high population density, rapid urban growth, and unique environmental conditions (Shober et al. 2010; U.S. Census Bureau 2011). Studies that quantify soil characteristics within a wide range of newly constructed urban residential landscape soils are needed to better understand the contribution of this source to water quality degradation.

The objectives of this study were to: 1) quantify soil characteristics and examine variability at plot-level and community-level scales within newly constructed urban residential communities located in three central Florida counties (Orange, Lake, and Seminole), and 2) examine relationships between soil characteristics and infiltration rates near the soil surface that would have the greatest influence on runoff potential. Data collected from this investigation will provide a more accurate description of urban soil characteristics. In addition, this information can be used by landscape planners to improve management practices and in selection of plant materials appropriate for anthropogenic environments.

\section{MATERIALS AND METHODS}

\section{Site Description}

A total of nine urban residential communities were sampled from the adjacent counties of Orange, Lake, and Seminole in central Florida between January and May 2009. Communities were undergoing construction at time of sampling and were selected based upon access and visual representation of local environmental variability. Communities contained a range of 11 soil series prior to development: Adamsville (Entisol), Apopka (Ultisol), Candler (Entisol), EauGallie (Spodosol), Millhopper (Ultisol), Myakka (Spodosol), Pomello (Spodosol), Smyrna (Spodosol), Sparr (Ultisol), Tavares (Entisol), and Zolfo (Spodosol). A total of 40 single-family unit lots within the nine communities were randomly identified and selected for sampling. An attempt to sample five lots within each of the nine communities was made; however, five lots were not available in each community. Thus, five lots were sampled in six of the communities, four lots were sampled in one community, and three lots were sampled in two communities. Average lot size was approximately 0.06 ha. All selected lots had been prepared for housing construction through land clearing, backfilling, and leveling prior to sampling. No residential structures or vegetation were present at sampled lots; however, underground site utilities had been installed.

\section{Sample Collection}

Five soil samples were collected at random locations within each lot using a soil core sampler (Model 200; SoilMoisture Equipment Corporation, Santa Barbara, California, U.S.). Soil cores sampled measured $5.7 \mathrm{~cm}$ in diameter and $3.0 \mathrm{~cm}$ in depth and were collected at a depth beginning $3.8 \mathrm{~cm}$ below soil surface to quantify soil characteristics near the soil surface. A Global Positioning System (GPS) unit (Model Nuvi 200; Garmin International, Inc., Olathe, Kansas, U.S.) was used to determine sampling location and position within Department of Agriculture-National Resource Conservation Service (NRCS) soil maps. One additional soil sample was collected from each lot using a soil auger (Model S-110; Durham Geo-Enterprises, Inc., Stone Mountain, Georgia, U.S.) at a depth of $0-3 \mathrm{~cm}$.

\section{Sample Analyses}

Three of the five soil core samples were used for determination of soil $\mathrm{D}_{\mathrm{b}}$. Cores were transferred to a laboratory oven (Model 18EM; Precision Scientific Group, Chicago, Illinois, U.S.) and dried for analysis using the standard method of Blake and Hartge (1986). Soil core sample mass was measured using a top-loading balance (Model PB5001; Mettler Toledo, Inc., Columbus, Ohio, U.S.).

Two of the five soil core samples were used for determination of soil moisture retention characteristics. Cores were saturated under vacuum then placed in a ceramic plate extractor (Model 1500F1; SoilMoisture Equipment Corp.) and analyzed in accordance with ASTM method D6836 (ASTM 2008). Moisture extraction was examined at 6.4, 9.8, 19.6, 39.2, 100, 500, and $1500 \mathrm{kPa}$ to develop moisture retention characteristics. Sample mass at each pressure interval was recorded (Model PB5001; Mettler Toledo, Inc.). In addition to examining moisture retention characteristics, soil moisture data were used to quantify soil pore size distribution using the method of Klein and Libardi (2002). The soil sample collected with the auger was analyzed for particle size distribution for textural determination using the standard method of Gee and Bauder (1986).

One soil infiltration rate measurement was collected randomly within each lot using a falling head double-ring infiltrometer. The double-ring infiltrometer was constructed of polyvinyl chloride pipe measuring $30.5 \mathrm{~cm}$ in length. This device had an outer ring diameter of $10.2 \mathrm{~cm}$ and an inner ring diameter of $5.1 \mathrm{~cm}$. Both rings were installed to a depth of $10 \mathrm{~cm}$ below soil surface prior to measurement. Infiltration tests were conducted for a duration of 40 minutes (infiltration was observed to become constant within 15 minutes or less of test initiation).

\section{Statistical Analyses}

All data were analyzed by analysis of variance using the PROC GLM procedure in SAS with mean separation by Tukey-Kramer unless otherwise specified (SAS Institute 2008). Statistical analysis of $\mathrm{D}_{b}$ was conducted comparing mean values among lots and communities. Florida's soil is dominated by sand particle size fractions $(0.05-2 \mathrm{~mm})$, thus mean comparisons of percentage sand among communities was conducted by Duncan's multiple range test. Analysis of soil moisture characteristics compared mean soil moisture retention volumes between soil moisture potentials 6.4 and $100 \mathrm{kPa}$ among lots and communities. This matric potential range was selected because it best represents the range of soil moisture available for plant uptake in predominately sandy soils (Obreza et al. 1997). Mean comparisons of soil infiltration rates were analyzed among communities. Coefficient of variation was determined for $D_{b}$, soil porosity, and soil moisture retention volume data using the PROC MEANS procedure in SAS (SAS Institute 2008). Regression analysis was conducted to examine relationships between soil infiltration rates, $D_{b}$, soil moisture retention volumes, and percentage of soil sand, silt, and clay using the PROC REG procedure in SAS (SAS Institute 2008). All analytical tests were considered to be statistically significant if $P<0.05$. 


\section{RESULTS AND DISCUSSION}

\section{Soil Textural Classification}

The proportion of sand within lots ranged from $81.9 \%$ to $97.8 \%$ (data not shown), while the mean proportion of sand within communities ranged from $91.0 \%$ to $96.4 \%$. Sand particle size fractions dominated soils (Table 1). Textural analysis determined $90 \%$ of soils (36 lots) were classified as sand, with only three lots containing loamy sand and one lot containing a sandy loam. Although the proportion of sand varied between samples, no difference in the total percent of sand could be found. Similar percentages of soil sand $(89.3 \%$ to $96.2 \%$ ) were observed in a related study in north-central Florida (Gregory et al. 2006) and are typical within central Florida (Brown et al. 1990). Medium (0.25 to $0.5 \mathrm{~mm})$ and fine $(0.1$ to $0.25 \mathrm{~mm}$ ) sand particle sizes dominated the sand fraction, with means of 386.2 and $455.1 \mathrm{~g} \mathrm{~kg}^{-1}$ soil, respectively (Table 1) (USDA 1995). Coarse sand particle $(0.5$ to $1.0 \mathrm{~mm})$ size fractions were minimal and ranged from 3.2 to $64.7 \mathrm{~g} \mathrm{~kg}^{-1}$ soil.

NRCS soil maps indicated that the sampled areas were mapped as Spodosols, Entisols, and Ultisols prior to urban residential development (NRCS 2011). These soil orders are common throughout Florida and the southeastern U.S. region (Brady and Weil 2002). Results of textural classifica- tion analysis were similar to soil descriptions listed in NRCS soil maps for most $(90 \%)$ sampled locations. In lots where soil textural classification differed from the NRCS soil map description, clay content of soil was consistently higher. This most likely was due to the use of non-native soil in site leveling and grading activities (C.R. Glagola, pers. comm.).

\section{Pore Size Distribution}

Total soil porosity ranged from 38.8 to $46.8 \mathrm{~cm}^{3} 100 \mathrm{~cm}^{-3}$ soil (Table 2). Mean macropore and micropore soil volume was 9.6 and $24.7 \mathrm{~cm}^{3} 100 \mathrm{~cm}^{-3}$ soil, respectively. Micropores (diameter $0.05-0.0002 \mathrm{~mm}$ ) were the dominant soil pore size among sampled lots, representing $58 \%$ of total mean soil pore space. Macropores (diameter $>0.05 \mathrm{~mm}$ ) and cryptopores (diameter $<0.0002 \mathrm{~mm}$ ) represented $22 \%$ and $20 \%$ of total mean soil pore space, respectively. The coefficient of variation for mean macroporosity within each lot ranged from $1.2 \%$ to $123.7 \%$, whereas variation within communities ranged from $35.7 \%$ to $85.1 \%$. High variability in macroporosity between replicate samples was likely a result of lithologic discontinuities resulting from construction activities (Craul 1985). Dominance of soil micropores restrict air and water movement (Tuli and Hopmans 2004; Tuli et al. 2005). This condition reduces infiltration rates and promotes urban stormwater "flashiness" dur-

Table 1. Soil particle size distribution of $\mathbf{4 0}$ lots within nine newly established urban residential communities in central Florida.

\begin{tabular}{|c|c|c|c|c|c|c|}
\hline \multirow[t]{2}{*}{ Community } & Coarse sand ${ }^{\mathrm{z}}$ & Medium sand ${ }^{y}$ & Fine sand ${ }^{\mathrm{x}}$ & Sand $^{\mathrm{w}}$ & Silt $^{v}$ & Clay $^{u}$ \\
\hline & \multicolumn{6}{|l|}{$\mathrm{g} \mathrm{kg}^{-1}$} \\
\hline 1 & $10.6 \mathrm{~b}^{\mathrm{t}}$ & $394.3 \mathrm{a}$ & $417.0 \mathrm{a}$ & $944.6 \mathrm{a}$ & $16.0 \mathrm{ab}$ & $39.4 \mathrm{a}$ \\
\hline 2 & $3.2 \mathrm{~b}^{\mathrm{t}}$ & $391.5 \mathrm{a}$ & $481.5 \mathrm{a}$ & $943.9 \mathrm{a}$ & $2.9 \mathrm{~b}$ & $53.6 \mathrm{a}$ \\
\hline 3 & $64.7 \mathrm{a}^{\mathrm{r}}$ & $252.8 \mathrm{a}$ & $489.1 \mathrm{a}$ & $892.9 \mathrm{a}$ & $51.9 \mathrm{a}$ & $55.3 \mathrm{a}$ \\
\hline 4 & $6.7 \mathrm{~b}^{\mathrm{t}}$ & $414.9 \mathrm{a}$ & $414.8 \mathrm{a}$ & $941.8 \mathrm{a}$ & $13.3 \mathrm{ab}$ & $45.1 \mathrm{a}$ \\
\hline 5 & $8.9 \mathrm{~b}^{\mathrm{q}}$ & $414.6 \mathrm{a}$ & $433.4 \mathrm{a}$ & $910.6 \mathrm{a}$ & $24.6 \mathrm{ab}$ & $64.9 \mathrm{a}$ \\
\hline 6 & $4.6 b^{t}$ & $413.1 \mathrm{a}$ & $464.4 \mathrm{a}$ & $919.3 \mathrm{a}$ & $21.5 \mathrm{ab}$ & $59.5 \mathrm{a}$ \\
\hline 7 & $7.4 a b^{r}$ & $438.3 \mathrm{a}$ & $422.7 \mathrm{a}$ & $921.8 \mathrm{a}$ & $12.5 \mathrm{ab}$ & $65.8 \mathrm{a}$ \\
\hline 8 & $29.4 a^{t}$ & $321.0 \mathrm{a}$ & $498.2 \mathrm{a}$ & $921.8 \mathrm{a}$ & $0.6 \mathrm{~b}$ & $89.5 \mathrm{a}$ \\
\hline 9 & $13.1 \mathrm{ab}^{\mathrm{t}}$ & $434.9 \mathrm{a}$ & $474.4 \mathrm{a}$ & $964.3 \mathrm{a}$ & $3.7 \mathrm{~b}$ & $32.3 \mathrm{a}$ \\
\hline
\end{tabular}

${ }^{\mathrm{z}} 0.5$ to $1.0 \mathrm{~mm}$ diameter particle size.

y 0.25 to $0.5 \mathrm{~mm}$ diameter particle size.

x 0.1 to $0.25 \mathrm{~mm}$ diameter particle size.

w 0.05 to $2 \mathrm{~mm}$ diameter particle size.

v 0.002 to $0.05 \mathrm{~mm}$ diameter particle size.

" $<0.002 \mathrm{~mm}$ diameter particle size.

${ }^{\mathrm{t}}$ Means of 5 replications. Means within columns not followed by the same letter are significant at $P \leq 0.05$ (Tukey-Kramer).

${ }^{\mathrm{r}}$ Means of 3 replications. Means within columns not followed by the same letter are significant at $P \leq 0.05$ (Tukey-Kramer).

${ }^{\mathrm{q}}$ Means of 4 replications. Means within columns not followed by the same letter are significant at $P \leq 0.05$ (Tukey-Kramer).

Table 2. Soil porosity of $\mathbf{4 0}$ lots within nine newly established urban residential communities within central Florida.

\begin{tabular}{lllll}
\hline Community & Total soil porosity & Soil macropores & Soil micropores \\
\cline { 2 - 5 } & $\mathrm{cm}^{3}$ pores $100 \mathrm{~cm}^{-3}$ soil & & \\
\hline 1 & $46.8 \mathrm{a}^{\mathrm{z}}$ & $7.1 \mathrm{c}$ & $32.3 \mathrm{a}$ & $7.4 \mathrm{~b}$ \\
2 & $42.7 \mathrm{abcd}^{\mathrm{z}}$ & $6.4 \mathrm{c}$ & $28.6 \mathrm{abc}$ & $7.7 \mathrm{~b}$ \\
3 & $40.8 \mathrm{abcd}^{\mathrm{y}}$ & $6.7 \mathrm{bc}$ & $23.9 \mathrm{abcd}$ & $10.2 \mathrm{ab}$ \\
4 & $38.8 \mathrm{~d}^{z}$ & $9.9 \mathrm{abc}$ & $23.2 \mathrm{bcd}$ & $5.7 \mathrm{~b}$ \\
5 & $45.3 \mathrm{ab}^{\mathrm{x}}$ & $10.9 \mathrm{abc}$ & $20.8 \mathrm{~cd}$ & $13.6 \mathrm{a}$ \\
6 & $45.1 \mathrm{abc}^{\mathrm{z}}$ & $16.1 \mathrm{a}$ & $19.0 \mathrm{~d}$ & $10.0 \mathrm{ab}$ \\
7 & $43.9 \mathrm{abcd}^{\mathrm{y}}$ & $15.9 \mathrm{ab}$ & $19.2 \mathrm{~cd}$ & $8.8 \mathrm{ab}$ \\
8 & $39.9 \mathrm{bcd}^{\mathrm{z}}$ & $6.5 \mathrm{c}$ & $25.5 \mathrm{abcd}$ & $7.9 \mathrm{ab}$ \\
9 & $42.1 \mathrm{abcd}^{\mathrm{z}}$ & $7.1 \mathrm{c}$ & $30.2 \mathrm{ab}$ & $4.8 \mathrm{~b}$ \\
\hline
\end{tabular}

${ }^{\mathrm{z}}$ Means of 10 replications. Means within columns not followed by the same letter are significant at $P \leq 0.05$ (Tukey-Kramer).

${ }^{y}$ Means of 6 replications. Means within columns not followed by the same letter are significant at $P \leq 0.05$ (Tukey-Kramer).

${ }^{x}$ Means of 8 replications. Means within columns not followed by the same letter are significant at $P \leq 0.05$ (Tukey-Kramer). 
ing intense precipitation events (Ehrenfeld et al. 2003; Baker et al. 2004). These conditions may be of concern in residential landscape soils where runoff conditions may contribute to nonpoint source pollution (Brett et al. 2005; Atasoy et al. 2006).

\section{Soil Moisture Retention Characteristics}

A soil moisture characteristic curve representing the mean moisture retention volumes of all collected samples is shown in Figure 1 . Approximately $42 \%$ of the total mean volumetric water content was held as gravitational water (0 to $10 \mathrm{kPa})$, while approximately $66 \%$ of the total mean volumetric water content was held between 0 and $100 \mathrm{kPa}$. The large percentage of water held at low pressure potentials was expected, given soils were dominated by sand particle size fractions. Mean soil moisture retention volumes of communities ranged from 16.5 to $28.5 \mathrm{~mL}$ water $100 \mathrm{~cm}^{-3}$ soil between moisture potentials 0 and $100 \mathrm{kPa}$ (Table 3). Significant differences in soil moisture content were observed among communities. The coefficient of variation for mean soil moisture content within communities ranged from $16.7 \%$ to $50.8 \%$ (Table 3 ). High variability between replicate

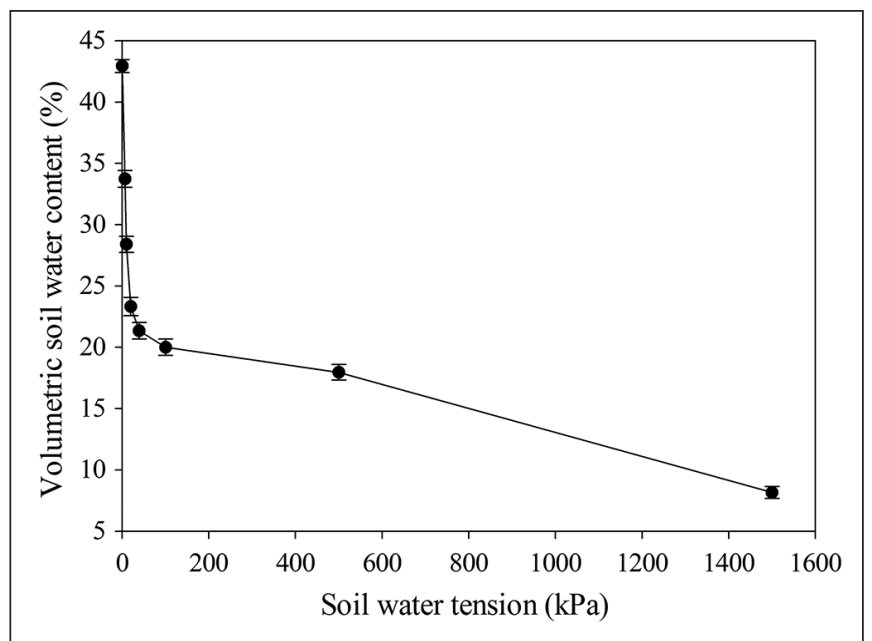

Figure 1. Mean soil water characteristic curve for all samples collected within nine newly established urban residential communities within central Florida. Error bars represent the standard error of the mean. samples was likely a result of heterogeneity in soil pore size and its correlated influence on soil moisture retention (Craul 1985; Jeetendra and Singh 2008). Low soil moisture retention values were a result of the high percentage of coarse, sandy textured soils (Goncalves et al. 2010). Soil moisture retention characteristics of urban residential soils have not previously been reported.

\section{Soil Infiltration}

Mean soil infiltration rates in communities ranged from 11.2 to $63.6 \mathrm{~cm} \mathrm{hr}^{-1}$. Significant differences were observed among communities (Table 3). High variability in soil infiltration rate was also observed within communities. The maximum recorded infiltration rate was $111.1 \mathrm{~cm} \mathrm{hr}^{-1}$, while the minimum rate was $2.0 \mathrm{~cm} \mathrm{hr}^{-1}$. Similar infiltration rates and variability has been observed in related studies $(0.3$ to $220.0 \mathrm{~cm}$ $\mathrm{hr}^{-1}$, Pitt et al. 1999; 0.8 to $17.5 \mathrm{~cm} \mathrm{hr}^{-1}$, Gregory et al. 2006).

Florida stormwater modeling and planning regulations require that management plans account for potential stormwater flow. Infiltration rates in $45 \%$ of sampled lots were below the 100-year, 24-hour design storm intensity of $26.7 \mathrm{~cm} \mathrm{hr}^{-1}$ for Orlando, Florida (FDEP 2006). Further, 30\% of sampled lots had infiltration rates below the 5-year, 24-hour design storm intensity of $16.5 \mathrm{~cm} \mathrm{hr}^{-1}$. Thus, a large percentage of sampled lots would likely produce stormwater runoff under intense precipitation events. Penetration of landscape plant material roots into compacted urban soil may increase infiltration. Bartens et al. (2008) observed a 63\% increase in mean infiltration rate as a result of black oak (Quercus velutina Lam.) and red maple (Acer rubrum L.) root penetration into compacted container soil. Authors attributed this observation to the formation of water channels along live root channels. Additional research examining the effect of plant material root growth on soil compaction and infiltration rate is needed.

\section{Soil Bulk Density}

Mean soil $\mathrm{D}_{\mathrm{b}}$ values ranged from 1.65 to $1.78 \mathrm{~g} \mathrm{~cm}^{-3}$ (Table 3 ). These values were similar to those observed by Gregory et al. (2006), where relationships between residential construction equipment use and soil compaction in northern central Florida were examined. Observed $D_{b}$ values were also simi-

Table 3. Soil characteristics of $\mathbf{4 0}$ lots within nine newly established urban residential communities in central Florida.

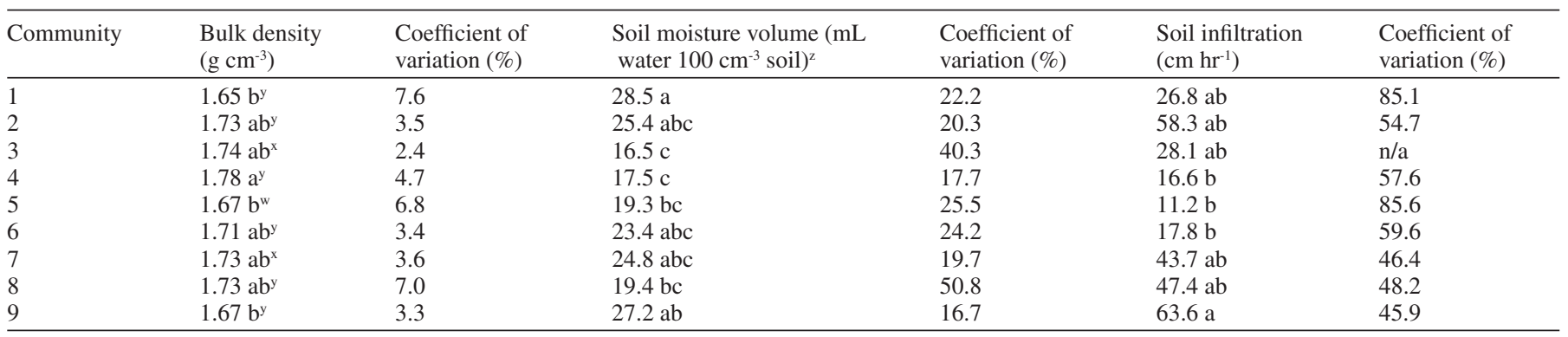

${ }^{\mathrm{z}}$ Soil moisture volumes calculated between soil matrix potential 0 and $100 \mathrm{kPa}$.

y Means of 15, 10, and 5 replications for bulk density, soil moisture volume, and soil infiltration, respectively. Means within columns not followed by the same letter are significant at $P \leq 0.05$ (Tukey-Kramer).

${ }^{x}$ Means of 9,6 , and 3 replications for bulk density, soil moisture volume, and soil infiltration, respectively. Means within columns not followed by the same letter are significant at $P \leq 0.05$ (Tukey-Kramer).

w Means of 12, 8, and 4 replications for bulk density, soil moisture volume, and soil infiltration, respectively. Means within columns not followed by the same letter are significant at $P \leq 0.05$ (Tukey-Kramer). 
lar to those found in newly constructed urban residential communities within Idaho and Washington states (Scharenbroch et al. 2005). Over $50 \%$ of sampled communities had mean $D_{b}$ values of approximately $1.75 \mathrm{~g} \mathrm{~cm}^{-3}$. When compaction density exceeds this value in predominately sandy soils, plant root soil penetration can be negatively impacted (Daddow and Warrington 1983; Voorhees 1992). Ensuring soil compaction remains below this threshold may be necessary when attempting to successfully transplant and establish plant materials in similar, newly constructed residential landscapes. Delineation of construction traffic zones are recommended to minimize unintended soil compaction (Randrup and Dralle 1997). Postconstruction mechanical loosening of compacted soil and addition of organic amendments are recommended to decrease $\mathrm{D}_{\mathrm{b}}$ and increase soil macroporosity (Rivenshield and Bassuk 2007).

Soil compaction in newly constructed urban residential communities within central Florida had low variability at both small (lot) and large (community) spatial scales and was likely the result of similar, unintentional soil compaction that resulted from site leveling and grading practices. Variability of $D_{b}$ within each sampled lot was low. Coefficient of variation of $\mathrm{D}_{\mathrm{b}}$ within communities ranged from $3.3 \%$ to $7.6 \%$ (Table 3 ). Several individual lots were observed to have significantly greater $\mathrm{D}_{\mathrm{b}}$ values than other lots within the same community (data not shown). This trend was random and likely a result of additional site traffic or equipment storage on these lots. Visual observation was made of construction equipment and vehicular storage on random lots at the time of sampling. Efforts to avoid these lots during sample collection were made; however, it was not possible to determine if sampled lots had additional traffic-induced compaction prior to sample collection.

Although no housing structures were erected at the time of sampling, significant increases in soil compaction resulting from additional construction activities are not likely given the high soil compaction values already imposed. Assuming no additional soil disturbances occur, temporal decreases in $\mathrm{D}_{\mathrm{b}}$ are likely to occur as a result of improvements in physical, chemical, and biological soil characteristics (Scharenbroch et al. 2005).

Despite examining relationships between soil infiltration and soil moisture volume at various pressure deficits iteratively, no correlations were observed. Similarly, soil bulk density was not a significant predictor of infiltration rate here, although its relationship with infiltration is well established (Grabosky and Bassuk 1995; Jim 1998; Gregory et al. 2006; Pitt et al. 2008). Consistent construction practices likely caused uniformity among $D_{b}$ measurements, even though the study encompassed sites managed by various contractors. Regression analysis determined percentage total sand was the only significantly correlated variable to infiltration rate; however, percentage silt and clay were added to the model given their relationship to soil texture. Development of the regression model allowed for calculation of predicted infiltration rate. Relationships between recorded and predicted infiltration rate were examined (Figure 2). One outlier was omitted given its predicted value was $>2$ standard deviations from the recorded value. The coefficient of determination for the regression model was low $\left(r^{2}=0.43\right)$ and likely a result of high variability among recorded infiltration values.

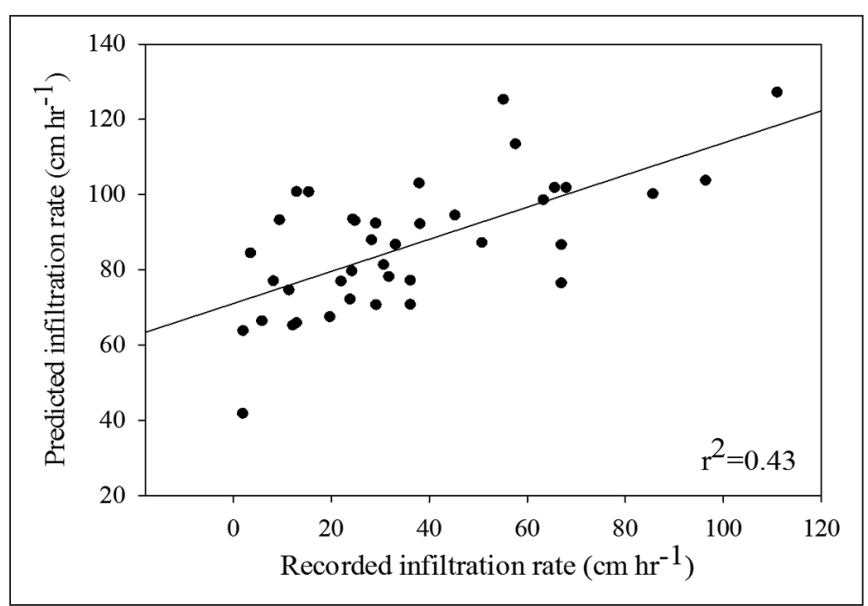

Figure 2. Regression of recorded infiltration rate (dots) and predicted infiltration rate of soil within nine newly established urban residential communities in central Florida. Predicted infiltration rate was calculated through the regression model: Infiltration predicted $=-1497.09+16.07(\%$ sand content $)+6.58(\%$ silt content $)+13.49$ ( $\%$ clay content $)$.

\section{CONCLUSIONS}

In conclusion, study results provide a characterization of sandy soils within newly constructed urban residential communities in central Florida. Consistent, high $\mathrm{D}_{\mathrm{b}}$ values indicate potential plant root penetration concerns, while variable soil infiltration rates suggest potential for stormwater discharge from urban landscapes during intense precipitation events. Delineation of construction traffic zones and application of soil amendments may mitigate high soil $\mathrm{D}_{\mathrm{b}}$ and low soil infiltration rates observed in urban soils. Additionally, penetration of landscape plant material roots may increase infiltration rate and decrease stormwater runoff potential. Correlations between soil moisture retention volumes, bulk density, and soil infiltration rate were not observed to occur; however, soil texture was found to be a significant predictor of soil infiltration rate. Poor relationships between soil characteristics and infiltration rate suggest that direct measurement of soil infiltration is necessary for accurate stormwater discharge estimation.

Accurate landscape soil characteristic data is imperative to effective stormwater management. Urban soil characteristics should be considered unique and different from native soils. Planning and design of landscapes should assume increase bulk density and reduced infiltration compared to native soils (Randrup 1997; Randrup and Dralle 1997; Gregory et al. 2006). If stormwater management plans do not recognize the unique characteristics of urban soils, improper strategies may be developed.

Acknowledgments. This work was supported by the Florida Nursery, Growers and Landscape Association. 


\section{LITERATURE CITED}

ASTM. 2008. Standard D6836, Standard Test Methods for Determination of the Soil Water Characteristic Curve for Desorption Using a Hanging Column, Pressure Extractor, Chilled Mirror Hygrometer, and/or Centrifuge. ASTM International, West Conshohocken, Pennsylvania, U.S.

Atasoy, M., R.B. Palmquist, and D.J. Phaneuf. 2006. Estimating the effects of urban residential development on water quality using microdata. Journal of Environmental Management 79:399-408.

Baker, D.B., R.P. Richards, T.T. Loftus, and J.W. Kramer. 2004. A new flashiness index: Characteristics and applications to midwestern rivers and streams. JAWRA Journal of the American Water Resources Association 40:503-522.

Bartens, J., S.D. Day, J.R. Harris, J.E. Dove, and T.M. Wynn. 2008. Can urban tree roots improve infiltration through compacted subsoils for stormwater management? Journal of Environmental Quality 37:2048-2057.

Beyer, L., H.P. Blume, D.C. Elsner, and A. Willnow. 1995. Soil organicmatter composition and microbial activity in urban soils. Science of the Total Environment 168:267-278.

Blake, G.R., and K.H. Hartge. 1986. Bulk density. In: G.S. Campbell et al. (Eds.). Methods of soil analysis. Part 1, Physical and mineralogical methods. Soil Science Society of America, Madison. Wisconsin, U.S. pp. 364-367

Brady, N., and R. Weil. 2002. Elements of the Nature and Properties of Soils. Pearson Education, Inc., Upper Saddle River, New Jersey, U.S. pp. $80-81$.

Brett, M.T., G.B. Arhonditsis, S.E. Mueller, D.M. Hartley, J.D. Frodge, and D.E. Funke. 2005. Non-point-source impacts on stream nutrient concentrations along a forest to urban gradient. Environmental Management 35:330-342.

Brown, R.B., E.L. Stone, and V.W. Carlisle. 1990. Soils. pp. 35-69. In: R.L. Myers and J.J. Ewel (Eds.). Ecosystems of Florida. University of Central Florida Press, Orlando, Florida, U.S.

Craul, P.J., 1985. A description of urban soils and their desired characteristics. Journal of Arboriculture 11:330-339.

Craul, P.J. 1991. Urban soil problems and promise. Arnoldia (Jamaica Plain) 51:23-32.

Daddow, R.L., and G. Warrington. 1983. Growth-limiting soil bulk densities as influenced by soil texture. WDG Report, WSDG-TN-00005.

Day, S.D., and N.L. Bassuk. 1994. A review of the effects of soil compaction and amelioration treatments on landscape trees. Journal of Arboriculture 20:9-17.

Ehrenfeld, J.G., H.B. Cutway, R.I. Hamilton, and E. Stander. 2003. Hydrologic description of forested wetlands in northeastern New Jersey, USA - An urban/suburban region. Wetlands 23:685-700.

FDEP. 2006. The Florida Stormwater Erosion and Sedimentation Control Inspector's Manual. In: Florida Department of Environmental Protection. Tallahassee, Florida, U.S.

Gee, G.W., and J.W. Bauder. 1986. Particle Size Analysis. pp. 404-408. In: G.S. Campbell (Eds.). Methods of soil analysis. Part 1, Physical and mineralogical methods. Soil Science Society of America, Madison, Wisconsin, U.S.

Goncalves, R.A.B., T.V. Gloaguen, M.V. Folegatti, P.L. Libardi, Y. Lucas, and C.R. Montes. 2010. Pore size distribution in soils irrigation with sodic water and wastewater. Revista Brasileira De Ciencia Do Solo 34:701-707.

Grabosky, J., and N.L. Bassuk. 1995. A new urban tree soil to safely increase rooting volumes under sidewalks. Journal of Arboriculture $21: 187-201$
Gregory, J.H., M.D. Dukes, P.H. Jones, and G.L. Miller. 2006. Effect of urban soil compaction on infiltration rate. Journal of Soil and Water Conservation 61:117(8)

Jeetendra, K., and A.K.P. Singh. 2008. Water retention characteristics and development of models for prediction of available water capacity of the soil. Indian Journal of Soil Conservation 36:169-171.

Jim, C.Y. 1998. Physical and chemical properties of a Hong Kong roadside soil in relation to urban tree growth. Urban Ecosystems 2:171-181.

Klein, V.A., and P.L. Libardi. 2002. Densidade e distribuição do diâmetro dos poros de um Latossolo Vermelho, sob diferentes sistemas de uso e manejo. Revista Brasileira de Ciência do Solo 26:857-867.

Lichter, J.M., and P.A. Lindsey. 1994. The use of surface treatments for the prevention of soil compaction during site construction. Journal of Arboriculture 20:205-209.

Lorenz, K., and E. Kandeler. 2006. Microbial biomass and activities in urban soils in two consecutive years. Journal of Plant Nutrition and Soil Science-Zeitschrift Fur Pflanzenernahrung Und Bodenkunde 169:799-808.

NRCS. 2011. U.S. General Soil Map. Accessed 07/07/2011. <http://websoilsurvey.nrcs.usda.gov/app/HomePage.htm>

Obreza, T.A., D.J. Pitts, L.R. Parsons, T.A. Wheaton, and K.T. Morgan. 1997. Soil water-holding characteristic affects citrus irrigation scheduling strategy. Proceedings of the Florida State Horticultural Society 110:36-39.

Pitt, R., J. Lantrip, R. Harrison, C. Henry, and D. Hue, 1999. Infiltration through disturbed urban soils and compost-amended soil effects on runoff quality and quantity. U.S. Environmental Protection Agency, Water Supply and Water Resources Division, National Risk Management Research Laboratory, Cincinnati, Ohio, U.S.

Pitt, R., C. Shen-En, S.E. Clark, J. Swenson, and O. Choo Keong. 2008. Compaction's impacts on urban storm-water infiltration. Journal of Irrigation \& Drainage Engineering 134:652-658.

Randrup, T.B. 1997. Soil compaction on construction sites. Journal of Arboriculture 23:207-210.

Randrup, T.B., and K. Dralle. 1997. Influence of planning and design on soil compaction in construction sites. Landscape and Urban Planning 38:87-92.

Rivenshield, A., and N.L. Bassuk. 2007. Using organic amendments to decrease bulk density and increase macroporosity in compacted soils. Arboriculture \& Urban Forestry 33:140-146.

SAS Institute Inc. 2008. SAS/STAT 9.2, Cary, North Carolina, U.S.

Scharenbroch, B.C., J.E. Lloyd, and J.L. Johnson-Maynard. 2005. Distinguishing urban soils with physical, chemical, and biological properties. Pedobiologia 49:283-296.

Shober, A.L., G.C. Denny, and T.K. Broschat. 2010. Management of fertilizers and water for ornamental plants in urban landscapes: Current practices and impacts on water resources in Florida. HortTechnology 20:94-106.

Tuli, A., and J.W. Hopmans. 2004. Effect of degree of fluid saturation on transport coefficients in disturbed soils. European Journal of Soil Science 55:147-164.

Tuli, A., J.W. Hopmans, D.E. Rolston, and P. Moldrup. 2005. Comparison of air and water permeability between disturbed and undisturbed soils. Soil Science Society of America Journal 69:1361-1371.

U.S. Census Bureau. 2011. Current Population Survey: 2010. U.S. Census Bureau, Washington, D.C.

USDA. 1995. Soil Survey Investigations Report. Report No. 45, Version 1.0. Lincoln, Nebraska, U.S. 305 pp. 
USEPA. 1994. National water quality: 1994 report to Congress (appendices). United States Environmental Protection Agency, Washington, D.C.

Voorhees, W.B. 1992. Wheel-induced soil physical limitations to root growth. Advances in Soil Science 19:73-95.

Brian J. Pearson (corresponding author)

bpearson@ufl.edu

Mid-Florida Research and Education Center

University of Florida

2725 South Binion Road

Apopka, Florida 32703, U.S.

Richard C. Beeson, Jr.,

Mid-Florida Research and Education Center

University of Florida

2725 South Binion Road

Apopka, Florida 32703, U.S.

Carrie Reinhardt-Adams

Department of Environmental Horticulture

University of Florida

1545 Fifield Hall

Gainesville, Florida 32611, U.S.

Michael Olexa

Food and Resource Economics Department

University of Florida

2126 McCarty Hall

Gainesville, Florida 32611, U.S.

Amy Shober

Department of Plant and Soil Sciences

University of Delaware

531 Townsend Hall

Newark, Deleware 19716, U.S.
Zussamenfassung. Obwohl sie überwiegend aus Sanden zusammengesetzt sind, ergaben Untersuchungen in neuen urbanen Siedlungsgebieten in Florida, dass die Böden eine relative große Spannbreite von Tonanteilen enthalten und dass viel fremder Boden importiert wurde. Oft sind diese Siedlungen um Oberflächenwasser konstruiert, wo heftige Sommerregenfälle und intensive Landschaftspflege Anlass zur Oberflächenwasserkontamination geben. Die aktuellen physikalischen Eigenschaften der Böden können wegen der Landschaftsgestaltung, Bodenverdichtung und dem Erdenimport von den bereits vor Jahrzehnten erstellten Bodenkarten abweichen. Wie viel Wechsel und welche Veränderungen auftreten, wurde selten quantifiziert. Diese Studie untersucht bodencharakteristische Daten von verschiedenen neu gestalteten urbanen Böden und untersucht die Beziehungen zu Bodeninfiltrationsraten. Es wurden Proben von 40 Standorten aus neun neu etablierten Siedlungsgebieten in Zentral-Florida gesammelt, um die texturale Komposition, die Körperdichte $\left(\mathrm{D}_{\mathrm{b}}\right)$, Feuchtigkeitspeicherfähigkeit und Porengrößenverteilung zu bestimmen. Die meisten Standorte (90\%) enthielten sandige Böden mit überwiegend Mikroporen (58\% durchschnittlicher Gesamtporenanteil). Abweichungen bei $\mathrm{D}_{\mathrm{b}}$ war niedrig und die meisten Siedlungen zeigten hohe Bodenverdichtungsraten $\left(>1.7 \mathrm{~g} \mathrm{~cm}^{-3}\right)$, was auf auftretende Probleme bei der potentiellen Durchwurzelung der Böden hinweist. Die durchschnittlichen Bodeninfiltrationsraten bei den Standorten waren hoch (11 to $64 \mathrm{~cm} \mathrm{hr}^{-1}$ ) mit großen Abweichungen (2.0 to $111.1 \mathrm{~cm} \mathrm{hr}^{-1}$ ). Beziehungen zwischen Bodenfeuchtigkeitsspeicherkapazität, $\mathrm{D}_{\mathrm{b}}$, und Infiltrationsraten traten nicht auf. Dennoch war die Bodenstruktur ein signifikanter Anzeiger der Infiltrationsraten. Beziehungen zwischen den Infiltrationsraten und Bodeneigenschaften waren gering $\left(r^{2}=0.43\right)$ und verdeutlichten, dass eine direkte Messung der Infiltrationsraten erforderlich ist. Hohe Infiltrationsraten, unabhängig von der Verdichtung, zeigen ein reduziertes Potential für Oberflächenwasserkontamination, wenn ausreichend natürliche Wirklängen die Landschaften vom Wasserkörper trennt.

Resumen. Aunque los suelos son principalmente arenosos, las observaciones en las nuevas comunidades residenciales urbanas de Florida sugieren rangos relativamente amplios en contenido de arcilla y la importación de suelos con otro tipo de texturas. A menudo, estas comunidades se construyen en torno a las aguas superficiales, donde las fuertes lluvias de verano y los mantenimientos intensivos de los paisajes preocupan por la contaminación del agua superficial. Debido a la escultura del terreno, a la compactación del suelo y a la importación de tierras, las propiedades físicas del suelo in situ pueden diferir de los mapas de suelos desarrollados décadas atrás. Pocas veces se ha cuantificado qué tanto cambia y qué cambios se produjeron. Este estudio examinó los datos característicos de suelos diversos, de nueva construcción y se examinó las relaciones con las tasas de infiltración del suelo. Se recogieron muestras de 40 lotes en nueve comunidades urbanas residenciales de reciente creación en Florida Central para cuantificar la composición de textura, densidad aparente $\left(\mathrm{D}_{\mathrm{a}}\right)$, retención de humedad y distribución de tamaños de poros. La mayoría de los lotes $(90 \%)$ contenían suelos arenosos dominados por microporos (58\% en total del espacio poroso). La variabilidad de $\mathrm{D}_{\mathrm{a}}$ fue baja en la mayoría de las comunidades exhibiendo alta compactación del suelo $\left(>1,7 \mathrm{~g} \mathrm{~cm}^{-3}\right)$, que puede indicar posibles problemas de penetración de las raíces de las plantas. Las tasas medias de infiltración del suelo en las comunidades eran altas $\left(11 \mathrm{a} 64 \mathrm{~cm} \mathrm{hr}^{-1}\right)$, con grandes variaciones $(2,0$ a $\left.111,1 \mathrm{~cm} \mathrm{hr}^{-1}\right)$. No se produjeron correlaciones entre los volúmenes de retención de humedad del suelo, $\mathrm{D}_{\mathrm{a}}$ y la tasa de infiltración. Sin embargo, la textura del suelo fue un predictor significativo de la tasa de infiltración. Las correlaciones entre las tasas de infiltración y las características del suelo fueron pobres $\left(\mathrm{r}^{2}=0,43\right)$ y sugieren que puede ser necesario la medición directa de la velocidad de infiltración. Las altas tasas de infiltración, a pesar de la compactación, indican una disminución en el potencial de contaminación de aguas superficiales, si existe un número suficiente de paisajes naturales con cuerpos de agua. 